\title{
Microcalcification Present in Neoplastic Tissue
}

National Cancer Institute

\section{Source}

National Cancer Institute. Microcalcification Present in Neoplastic Tissue. NCI Thesaurus.

Code C53254.

A finding of microcalcifications located within neoplastic tissue. 